\title{
Work Family Culture as a Corporate Culture
}

\author{
Sri Kusumawarti \\ Sociology \\ Airlangga University \\ Surabaya, Indonesia \\ sri.kusumawarti2@gmail.com
}

\begin{abstract}
As a formal organization, a company is a fully integrated entity for the achievement of goals. For the achieving goals, the company has the appropriate organizational culture. The background of this research is because the industrial environment requires a harmonious social relationship for the workers and the management company. Therefore, social relationships are shaped through cultures that exist in the daily interaction of individuals. A family culture that prioritizes the intimacy of intimacy rolling in the center of the company. Companies as industrial organizations must have a rational policy that may not be in harmony with the principle of family culture. According to Weber the organization has a bureaucracy that will dominate society because of its superior technique (Clegg, 1990). Company is an organization that will produce bureaucratic impact that is structural rigidity. Berger believes that the social reality that occurs can be expressed through social constructions. This study used qualitative methods, with a constructivist approach by looking at how languages and symbols, which are produced and reproduced are generated through a limited range of relationships between sources that accompany the process of the relationship. Research location is in PT Mulya Petra Panelindo, a company that adheres to the principle of family culture as a corporate culture. The research concluded that the concept of family culture is found in the middle of the employee is not out of the professionalism structure as the corporate context is as a formal institution. Professionalism in question is when a work problem, it will be discussed according to a structured division. Leaders as stakeholders are at the forefront of making changes. Corporate culture in the working environment feels warmer and not rigid. The growing process of familial culture in this company is an idea wanted by the company leader. Then the workers follow how the real culture is desired.
\end{abstract}

Keywords-Corporate Culture, Work family culture, Industry

\section{INTRODUCTION}

This study focuses on the social interaction of laborers with companies in the context of the process of establishing a corporate culture studied from the social construction approach. The company is an industrial organization that in achieving its objectives needs to implement an appropriate organizational culture. In the company, also found a cultural model that is certainly in accordance with the habits that occur within the scope of work. Today, family culture begins to be applied as an organizational culture in many companies. The research by Teguh Wijaya which reveals pharmaceutical companies in Surabaya applies a family culture to fulfill three functions. There are affection functions, maintenance functions, and empowerment functions. In fact, Korea's second conglomerate company LG is also implementing a family culture [1].

Work-family culture is still closely related to the collective organization culture proposed by Hofstede is developed in the eastern region that has special characteristics of working groups and a sense of family that is still thick, especially on the Javanese people. Companies that mostly work with Java tribe will focus on the work of groups, the harmony of each individual, each working together in the completion of specific work tasks [2].

Culture familial in business institutions felt less profitable. Culture familial tends to cultivate less professional working condition or less firm, and tend to occur excessive tolerance. Family culture will be appropriate when applied to social institutions (nonprofit), but will not / less appropriate when formed in business institutions/business [3].

Based on the description, the researchers are interested to know the meaning of corporate culture by employees, office staff and field workers. The research problem can be explained by several pieces of research focus, among others: Employee social construction of family culture in a company, and the process of growing family culture in the company. The paper shows how the use of the organization culture in this context is a new employer strategy within an industrial system. It provides insight into the corporate culture used as a tool of power by employers. The paper argues that the corporation which uses work-family culture, however, the labor still unstandardized that uses corporate culture as a hegemony.

\section{RESEARCH METHOD}

This research will be conducted in Surabaya city, located in Margomulyo Indah warehousing complex. According to the data encountered by the authors in the field of PT Mulya Petra Panelindo Company engaged in manufacturing factory machinery, there are values about work-family culture. In addition, corporate culture becomes important to be studied at PT Mulya Petra Panelindo because the company that still growing the capacity of about 150 employees. The developing companies have priority to increase the profit. The customary 
forms that inhibit the production process can't be tolerated. However, based on the information obtained that PT Mulya Petra Panelindo applies Corporate Culture with the principle of family. This is an interest to be studied about the corporate culture that exists in the company.

This research uses the qualitative method, with the constructivist approach. The constructivist approach was developed by Peter Berger and Thomas Luckman they developed this approach consistently. The basic assumption in this constructivist approach is that it is shaped and constructed differently by everyone.

This approach is more indirectly focused on a special scope. In the sense of seeing how languages and symbols are produced and reproduced through a limited range of relationships between sources that accompany the process of the relationship. In other words, it touches at the level of the micro level (self-concept of source) and the meso level (the environment where the source is located).

The data used in the study were gathered from in-depth interview and observation. Through in-depth interviews, researchers see the language and symbols produced and reproduced generated through these relationships. Furthermore, observations can provide data in the form of interactions that occur directly between employees.

Informant's way of determining refers to the informant's position on the problem to be studied. In this study, the informant was chosen based on his position as a staff or field worker. Researchers want to see the meaning difference between employees of staff or workers in the field. Furthermore, seen from the length of work, because in the formulation of the problem has been explained that this study wants to know the process of the growth of family culture in the company so to obtain information is needed informants who understand the development of the company. The researcher chooses at least employees who have worked for one to two years.

\section{RESULT}

\section{A. Corporate Culture}

Employee's understanding of corporate culture is the basic foundation of the company. Most corporate cultures are shaped by subsidiaries. The owner of the company is entitled to provide direction from the form of corporate culture that wants to run. The basic foundation that also includes company goals. Staff employees explain the meaning of the existing corporate culture is a family culture. The IR informant is the basic company held by the company.

This kinship culture is considered to understand all of its employees by embracing all employees and involvement in what issues the employee will be assisted in finding solutions by his boss. Assisting in solving this problem is considered appropriate, whether employees have problems it will interfere with his work, therefore the involvement of the company against the problems of employees felt necessary. In this case, the leader of the company is described as being concerned about the problems of his employees.
Family culture existing in the company today has one step that has not been achieved, namely the fulfillment of welfare, in terms of financing for employees. However, for the atmosphere and conditions in the work environment has reached the concept of family culture. Work-family culture is interpreted by employees is how the concern of the company leadership to employees problems, whether it is a problem outside of work or just in the work environment. And also there is no limit for employees to argue, even if it is an employee in the field when any problems are allowed to be submitted. Then, there is a good leadership image, which is considered caring and does not even look at the background of each employee, all employees are treated intimately, there is a treatment that respects employees. Exemplified when leaders want to attend if there is an invitation from employees. The IR informant said that even the highest leaders would attend the invitation by their employees even if it was in any condition.

The concept of family culture that is present in the middle of the employee is not out of the professionalism structure as the corporate context is as a formal institution. Professionalism referred to when there is a problem with the work, it will be discussed according to a structured division. A structured division has a person in charge of his division including when a problem is found.

\section{B. The Growing Process of work-family culture in the Company}

The growing process of family culture in this company is an idea wanted by the leadership of the company. Then the workers follow how the culture is actually desired by the company. As long as the existence of this family culture according to informants is a culture that is more concerned about its employees. Leadership attitude is often perceived as a form of family culture. The development of family culture is also considered not in the ideal position because there are still steps that have not been achieved as the achievement of welfare for employees. According to the meaning of family, culture informants should be able to prosper employees. However, because the company is still at a developing level then, the achiever is not yet reached. JM informant explained the financial condition of the company still not able to welfare all employees because the company is still the process of developing.

Cultural differences that occur between staff of employees and field workers are from the existing work system. But the concept of kinship is the same, the culture that is in the office is on the staff or even in the field that is field workers. This happens because the leadership does not provide restrictions for its employees to issue opinions.

\section{DISCUSSION AND CONCLUSION}

The corporate culture of PT Mulya Petra has the following characteristics: (1) is a concept that originates from the idea of leadership, and is accepted by employees, (2) is a shared value system shared by all members of social groups, (3) dynamically over time, (4) contains symbolic traits and arises on the basis of people's ability to create symbols of value, (5) 
indicates patterns of order, and is integrated as a collective agreement, (6) has adaptive abilities because although born from the idea of a corporate culture leader is a manifestation of the mechanism of environmental adaptation.

According to Weber's theory of bureaucracy is very closely related to the organization, both government organizations and private organizations. However, individual factors in organizational culture greatly affect bureaucracy. So the individual who determines the sustainability of the organization. Organizational culture can be directed to drive work-oriented development as a member of the organization of the enterprise.

\section{REFERENCES}

[1] P.M Blau, "Bureaucracy in Modern Society," New York: Random House, 1971.

[2] W.L. Neuman, "Social Research Methods: Qualitative and Quantitative Approach," Boston: Pearson, 2011.

[3] N. Patria, (Antonio Gramsci, State and Hegemony) "Antonio Gramsci Negara \& Hegemoni," Yogyakarta: Pustaka Pelajar. 2009. 